\title{
On the Visual Organs in Lamellibranchiata.
}

\author{
By
}

\begin{abstract}
Benjamin Sharp, Dr. med. et phil.,
Professor of the Lower Invertebrata at the Academy of Natural Sciences of Philadelphia, U.S.A.
\end{abstract}

With Plate 26.

\section{Introduction.}

My attention was first drawn to this subject by observing a number of Solen vagina which were exposed for sale in large basins at Santa Lucia in Naples. By passing my hand over the basin I noticed that those Solen upon which the shadow of my hand fell, instantly withdrew their siphons, while those not touched by the shadow remained as before, immovable. Obtaining some specimens at the Zoological Station I repeated the experiment and was convinced that the animals possessed some power of distinguishing light from darkness. This led me to examine the minute structure of the siphon carefully and my search was rewarded by the discovery of a very primitive form of visual organ, so primitive in fact that the term e ye can hardly be applied to it.

I wish here to extend my thanks to the Bavarian Government for allowing me the use of its table during the months of March, April and May of 1883 and also to the director, Professor A. DoHrs, and his assistants at the Zoological Station, while in the pleasant company of the latter I received much advice and assistance.

Part of the material only came from Naples namely Solen vagina, Pecten jacobaeus, Patella coerulea, and Haliotis tuberculata. Solen ensis, Venus mercenaria, Ostrea virginica and Mactra solidissima came from the coast of New Jersey, U. S. A., and Mya arenaria from Boston, Mass., U.S. A. The specimens of Anomia ephippium and Mytitus edulis I collected at Villafranca, France. I am indebted to the curators of the Acad. of Nat. Sc., for the use of all other matcrial. 


\section{Historical.}

In working up the literature of this subject, I find, that with the exception of WILL and SIEBOLD, all the authors have confined their attention to the asiphonated forms and especially to the well known eye of Pecten.

J. X. PoLI ${ }^{1}$ in 1795 was the first to mention the fact that any of the Lamellibranchiata possessed eyes. He pointed out that Ostrea (pecten) jacobaea and Spondylus gaederopus possessed small bright ocelli distributed on the edge of the mantle in considerable numbers. He figures and gives a short account of their external anatomy.

In $1834 \mathrm{R}$. Garner ${ }^{2}$ describes the eyes of Pectcn, Spondylus, and Ostrea as being »small, brilliant, emerald-like ocelli, which from their structure, having each a minute nerve, a pupil, a pigmentum, a striated body and a lens; and from their situation at the edge of the mantle, where alone such organs could be useful, and also placed as in Gastropoda with tentacles, must be organs of vision". As far as this goes it is correct and is the first description of the minute anatomy of this organ.

In 1840 two authors added to our knowledge on this subject, A. E. GRUBE ${ }^{3}$ and A. Krohn. The former laid down the law that invertebrate as well as vertebrate animals that are free to move about in the air or water, possess eyes in order to recognize their surroundings and to direct their movements ${ }^{4}$.

He then says that snails possess eyesight and that acephales are blind and this is owing to their stationary condition. The only two genera, among the acephales, according to GRUBE, that can see are Lima and Pecten and these do not form exceptions to the rule as they have the power to move about from place to place by clapping their shells. He then enters into the anatomy of the eye and considers it in the three forms of Pecten jacobaeus, $P$. opercularis and $P$. varius.

1 J. X. Poli, Testacea utriusque Sieiliae eorumque historia et anatome tabulis aeneis illustrata. Parmae 1795. Vol. II. p.107. Spondylus Tabula XXII fig. 1, 2, 4 et 5. Pecten Tabula XXVII fig. 5, 14 et 15 .

2 R. GARNER, On the nervous system of molluseous animals. Trans. of the Linnean Society. Vol. XVII. Pt. IV. p. 485 et seq. London 1834. p. 488.

3 A. E. Grube, Über Augen bei Museheln. MüLler's Arehiv fuir Anat. und Physiol. Berlin 1840, p. $23 \mathrm{ff}$.

4 "Dass Thieren mit freierer Ortsverïnderung in Luft oder Wasser Augen gegeben sind, um ihre Umgebungen zu erkennen und danaeh ilıre Bewegungen einzuriehten." 
A. Krohs's ${ }^{1}$ account is much fuller as to anatomy of the eye of Pecten and goes far ahead of that of any of his predecessors. He was the first to point out the existence of two nerves passing to the eyeball, these two being the splitting of the main nerve in the pedicle of the eye.

In 1844 WILL 2 investigated a number of Lamellibranchiata and found that a great many of them possessed eyes of great complexity. I have, unfortunately, been unable to consult the original article and know it only through Troschel's Jahresbericht for $1844^{3}$, and what subsequent authors have quoted or made reference to.

C. TH. v. Siebold in his Comparative Anatomy of the Invertebrata ${ }^{4}$ sustains the observations of WILL.

It is here said that the eyes of Pholas, Solen, Venus and Mactra are not on pedicles, but situated at the bases of the tentacles. In Cardium there is an extremely large number of contractile pedicles on the ends of which are the eyes; Tellina has the edges of the mantle set with small pedunculated eyes of a reddish yellow color; Pinna has on the anterior mantle edge forty short pedunculated yellowish brown eyes, while in Arca and Pectunculus are a large number of brownish red ones; Anomia, a form not investigated by WILL, has twenty brown sessile eyes situated between the numerous tentacles; in Ostrea the visual organs are the most numerous, and the most distinct eyes are found in Pecten.

M. Duvernoy ${ }^{5}$ in 1852 gave a short description of the eye fof Pecten maximus, but adranced nothing new on this head and did not enter into the histology at all.

1 A. KROHN, Übcr augenähnliche Organe bei Pecten und Spondylus. MÜLLER's Archiv für Anat. und Physiol. Bcrlin 1840. p. $371 \mathrm{ff}$.

${ }^{2}$ Will, Über die Augen der Bivalven und Ascidien. Froriep's Neue Notizen a. d. Gebiete der Natur- und Heilkunde. Bd. XXIX. Wcimar 1844. p. 81
und p. 99 .

3 Arehiv für Naturgeschichte. XI. Jahrg. Bd. II. Berlin 1845. p. 297 : "WILL stellte Untersuchungen ïber die Augen der Muscheln an. Er fand dieselben selır hoch organisirt. Außer bei Pecten, Spondylus, Ostrea fand sie dersclbe aueli bei Pinna, Arca, Pectunculus, Mytilus, Cardium, Tellina, Mactra, Vemus, Solen, Pholas, zuweilen in ungeheurer Zahl. Aueh bei den Aseidien Cynthia, Phallusia und
Clavellina wurden Augen nachgewieseu, und zwar 14, von denen S der Athem-
und 6 der Afterröhre angönon." und 6 der Afterröhre angchören."

4 C. Tr. v. Siebold, Lehrbuelı der vergleiehenden Anatomie der wirbellosen Thiere. Berlin 1845. p. 262 u. 263.

${ }_{5}^{5}$ M. Duvernoy, Mémoirc sur le Système Nerveux des Mollusques Aeéphales, Lamellibranches ou Bivalves. Mém. de l'Acad. des Se. de l'Inst. de France.
Tome XXIV. 1854. p. $69 \mathrm{ff}$. 
W. Keferstein ${ }^{1}$ investigated the eye of Pecten maximus and entered into a detailed account of the minute structure and supposes, as does LEYDIG ${ }^{2}$, that it closely resembles a compound arthropod eye.

$\mathrm{V}$. Hensen ${ }^{3}$ in 1862 gave by far the most complete account that we have of the eye of Pecten. He investigated the eyes of Pecten jacobaeus and Arca sp. (?) He entered into a minute account of the anatomy and histology of the eye a summary of which will be given later in its proper place (p. 456). He also investigated the forms described as possessing eyes by WILL, but was in the majority of cases utterly unable to find any trace of visual organs ${ }^{4}$.

In the last edition of C. Gegenbaur's Comparative Anatomy ${ }^{5}$ he says, after considering the embryonic eyes of those mollusca which are blind in the adult state, that Arca, Pectunculus, Tellina, Pinna etc. have the organs (eyes) on special optic stalks; then after referring to Pecten and Spondylus, he says: "Although these organs have many peculiarities of structure, they agree in all essential points with the optic organs of the rest of the Molluscar.

S. J. Hicksos ${ }^{6}$ in 1880 takes up the eye of Pecten jacobaeus, $P$. opercularis and $P$. maximus considering carefully the minute anatomy. He differs from Hensen in some points regarding the lens.

E. O. Schuid T ${ }^{7}$ in 1882 gives a short general account of the eye of Pecten sp. (?) and rather doubts the fact of its being purely an organ of vision, observing that it is quite possible that it has another signification.

The last paper bearing upon this subject is a short note on the eye of a species of Spondylus by S. J. Hickson (1882) ${ }^{8}$. He finds that

1 W. Keferstein, Untersuehungen iiber niedere Seethiere. §IX. Über den Bau der Augen von Pecten. Zeitsehr. f. wiss. Zool. Bd. XII. Leipzig 1862. p. 133 ff.

2 Fr. Leydig, Lehrbueh der Histologie der IIensehen und der Thiere. Frankfurt a. M. 1857.

3 V. Hensen, Über das Auge einiger Cephalopoden. Zeitselır. f. wiss. Zool. Bd. XV. Leipzig 1865. p. 220 ff.

${ }^{4}$ p. $221 \mathrm{Anm}$. : "Es wäre mir sehr lieb gewesen, wenn ich noeh einmal frisehe Augen hätto priifen künnen, aber bei erneuter und, wie ieh meine, sorgsamer Priifung der Auster und bei friiherer Prüfung von IIya und Cardium habe ieh trotz WILL's Angaben keine Augen finden können."

5 C. Gegenbaur, Elements of Comparative Anatomy. Engl. edition by F. JeFfrey BelL. London 187S. § 272. p. 353.

6 S. J. Hicrson, The eye of Pecten. Quart. Journ. of Mier. Se. N. S. Yol. XX. London 1880.

7 E. 0. Sormin't, Handbueh der vergleiehenden Anatomie. 8. Anff. Jena 1882.

8 S. J. Hickson, The eyo of Spondylus. Quart. Journ. of Mier. Se. N. S. Vol. XXII. London 1882. 
the eye of this form is essentially the same as that of Pecten and differs from it only in a few particulars.

The paper of Delle Chiaje ${ }^{1}$ referred to by Hensen ${ }^{2}$ and two short papers of J. CHatis ${ }^{3}$ referred to by Hickson I have not been able to find, and have to depend on the references for my knowledge of them.

The apparent disorder in the following pages may be perhaps explained here. I first examined in detail the histology of Solen vagina and $S$.ensis. I was then led to take up the other forms, namely: Ostrea, Mya, Venus, Mactra etc., as I could obtain them, and when fully satisfied with my results I went through the alcoholic collection of Lamellibranchiata of the Academy of Natural sciences, which I am sorry to say is not rich, neither are the specimens well preserved, and I am consequently in doubt as to many forms.

I then arranged the species that I had examined by families in their order beginning with the lowest; thus reversing the order of Tryon 4 in his Conchology.

This accounts for the fact that the detailed descriptions are scattered about.

I may here express my thanks to Mr. Tryon for his kind assistance in determining for me many of the species.

In entering now upon the special part of this paper I intend taking up in order the different forms of Lamellibranchiata that have been examined by myself and others. Owing to the bad condition of a number of the forms that I have examined I can give but fragmentary notes concerning them.

Taking up first the order Asiphonida I will first consider the

\section{Fam. Ostreidae.}

Ostrea virginica Linn. When the anterior border of the mantle of this species is examined it is found to be fringed with innumerable little tentacles ranging from $1 \mathrm{~mm}$ to $2 \mathrm{~mm}$ in length and arranged in three

1 Delle Chinje, Osscrvazioni anatomiche sull' occhio umano.

2 V. HENSEN, Über das Auge ctc. 1865. p. 158 and 222.

3 J. Chatris, Bullotin de la Société Philomatique. Paris 1877.

4 G. W. Tryos, jr., Structural and systematic Concholngy : an introduction to the study of the Mollusca. Philadelphia 1S84. Vol. III. p. 116 et seq. 
irregular rows. Inside of the inner row of tentacles is found a pigmented band differing greatly in intensity in different individuals.

$I$ have sought in vain for any appearance of distinct eyes in this part, or in any part, of the mantle; and further none have been revealed by studying carefully a complete series of sections of the mantleborder.

It has been asserted by Garner, WILL and Siebold that Ostrea possessed eyes of great complexity. They may have examined certain forms that I have been unable to obtain, but as far as Ostrea virginica and $O$. edulis are concerned, I can state that no complex eye exists, nor any evidence to support their assertions. That these animals possess a limited power of vision there is no doubt, as it has been asserted by my friend Mr. J. A. RYDER', a most careful observer, that when a shadow passes over the extended edge of the mantle it is instantly retracted.

I will now take up the minute anatomy of this part, and endeavour to point out the seat of vision.

When a vertical section of the anterior border of the mantle is made we find the free edge thrown into three distinct folds (fig. $1 a, b, c$ ). These are evidently longitudinal sections of the tentacles already spoken of. At the base of the central fold $(b)$ is seen the transverse section of the large circumpallial nerve (fig. $1 P . N$. .). This nerve according to DuvernoY ${ }^{2}$ comes from the principal or posterior ganglion. In the same section it can be seen giving off branches into the tentacles. The circumpallial nerve docs not consist entirely of nerve fibres, but ganglion cells may be seen scattered through it.

The body of the mantle is composed of muscular and connective tissue fibers, which cross each other in all directions, and imbedded in them may often be seen distinct nuclei. Between these fibers may be seen the blood spaces or lacunae (fig. 1 b.s.).

Passing through this mass of connective tissue, perpendicularly to the circumpallial nerve is seen a bundle of muscular fibers (fig. $1 \mathrm{r.m}$.); this bundle divides and, when a series of consecutive scetions are examined, they may be secn to become fastened to the epithelial layer that forms the external covering of the wholc mantle. One branch, seen in the figure (fig. $1 \mathrm{~d}$ ), passes to the basc of onc of thesc folds. Thesc bands

1 J.A. Ryder, Primitive visual organs. Science. Vol. II. Cambridge, Mass. 1883. p. 739.

2 Duvernoy, Mém. s. 1. syst. nerv. etc. 155t. p. 55. 
serve to retract the edge of the mantle within the shell, so that it will not be injured when the two shells meet.

Besides these retractor muscles are seen the extensor muscles (fig. 1 e.m.), which in the section are cut transversely. This muscle when it contracts forces the mantle outward. These muscles naturally are placed on the internal surface (fig. 1 B.S.) of the mantle and are attached at intervals to the shell.

Covering the whole external surface of the mantle is an epithelium of columnar cells which may be classed under two heads, namely: that which lies in contact with the shell and cuticle (fig. 1's.e.), and that lining the mantle which is directed toward the branchial cavity (fig. 1 b.e.). The former (s.e.) are much longer and larger, and the surface on which they are situated is thrown into a great number of folds, these are probably stretched out when the mantle is fully extended. These cells are very slender and it is very difficult to distinguish the separate cells. The nuclei, which have the shape of long sphaeroids, are situated at the deeper third of the cell and are very small and very narrow. These cells secrete the nacre which forms the internal layer of the shell.

The branchial epithelium (b.e.), which for us is the most important, forms a strong contrast with that lying next to the shell. The cells forming it are much smaller but more distinct. This epithelium is not thrown into folds as the other, but forms a continuous layer on the internal wall of the mantle.

These so-called pallial epithelial cells, however, are not all alike, for if we examine them closely we find a number of them pigmented. The cells containing pigment seem to be most numerous and best developed between the inner two folds (fig. 16 and $c$ ) of the mantle border. Pigmented cells are also found scattered along the pallial side of the mantle, and these are the cells which form the black band before mentioned.

In examining these pigmented cells with a higl power we fiud them very peculiarly constructed. They are columnar cclls possessing a very large and almost spherical nncleus. At the free end, or that part dirceted toward the exterior world, we find that there is a collection of fine pigment granules of a dark brown color (fig. 2). This pigment occupies the outer fourth of the cell and does not seem to be of equal thickness, being thinner in the centre or axis of the cell. The rest of the cell is filled with a granulated protoplasm in which is embedded the large nucleus. The nuclens is nearest the tunica (fig. $2 t$ ) on 
which the cell is plaeed. As is seen in the figure all the cells are not of the same shape. There is one set $(a)$ in whieh we have the pigmented portion at the broadest part of the cell, the base in fact; the other part of the cell tapers to the tunica. These eells possess a nucleus which appears oval. In the other set, in which the nuclens is spherical, the proportions are reversed, the broad base resting on the tunica, while the apex is wedged in between the bases of the other set. I am not prepared to say whether the cells of this set contain pigment, as they are very small and the end that passes outward is so fine, that, although I used a strong immersion lense of ZEIss I was unable to satisfy myself fully on this point.

On the top or external part of the cell there is seen a transparent membrane (fig. $2 \mathrm{c}$ ), which seems to be continuous over all the pigmented cells. It is of a lomogeneous nature, highly refractive, and takes no color in either picro- or borax-carmine. When the epitheliuu is separated from the underlying cutis, and the cells that compose it are a little scattered, this transparent membrane or cutiele, if it may be so called remains intact, that is, each cell is broken off from it leaving it umbroken. It may be seen projecting beyond the cclls, which are represented in the figmre (fig. $2 \mathrm{c}$ ).

On those cells possessing a cuticle no cilia could be detected. A cuticle is probably formed by each cell and then these separate pieces become welded together so as to form a continuous whole.

FraIsSE $^{1}$ found something similar to this in the eye of Fissurella, that is to say, he found non-pigmented cells between the pigmented ones and supposed these latter to form the lense and vitreous humor. But in Ostrea I am inclined to believe that each cell produees the cuticle which overlies it.

Now it is my opinion that the seat of vision is situated in these pigmented cells with a highly refractive cuticle. This view is supported by the fact that similar cells are found in Patella by Fraisse ${ }^{1}$ w he re no lens whatever is present. This point will be considered later on.

I may call attention here to the so-called epidermis (really euticle, fig. $1 \mathrm{cu}$.) of the shell passing in between the external fold $a$ and middle fold $b$. This membrane is formed by the cells lining the internal side of the external fold.

1 P. Fraisse, Über Molluskenaugen mit embryonalem Typus. Zeitschr. f. wiss. Zool. Bd. XXXV. Leipzig 1881. p. 461. 
As regards the other species that I have examined - Ostrea edulis, I may say that we have essentially the same state of affairs here as in $O$. virginica. I found no evidence of differentiated cyes on the mantle edge, that have been spoken of by former writers on the subject. This is probably the form that the European writers have investigated.

\section{Fam. Anomidae.}

Anomia ephippium has according to Srebold twenty brown sessile eyes sitnated between the numerous tentacles. In this as in the preceding form I was unable to find any evidence of a differentiated eye.

The mantle, which is capable of being contracted to a considerable distance within the shell, is densely set with tentacles. The upper border of the mantle is strongly pigmented and thrown into regular folds; from the bases of these folds spring the non-pigmented tentacles, thus causing the pigmented surface to round up, and this is what SIEBoud mistook for the sessile eyes. On the lower border ${ }^{1}$ we find scarcely any pigment at all, and this side of the mantle forms a strong contrast with the opposite mantle border. The pigment that is present in the lower border is collected into little spots lodged at the bases of the numerous folds into which the mantle is thrown. The tentacles here are also not pigmented and are about as numerous as they are on the upper border.

These small dots of pigment may also have been mistaken for eyes by Srebold.

Now by carefully examining a series of sections of the mantle border I found no trace of nsessile eyes«. The pigment is black and in very regular spherical granules deposited only in the epithelial cells. The characteristic refracting cuticle is present, but not so distinct as in Ostrea.

I have unfortunately no experimental evidence in this species, that any visual power is present, but from the form of the cells and that SIEBOLd supposed eyes to be prescnt, I think I can safcly assime that such is the case.

\section{Fam. Pectinidae.}

Pecten. The species of this family have been generally those taken for the investigation of the cye among the Lamellibranchiata, and the

1 I use the term upper and lower, instead of right and left for convenienee. The term lower being that whieh is on the shell, which is attached to the foreign
body. 
anatomy and histology of this complex organ has been well worked out. In passing it is strange to note that although many authors have stated that other forms possessed well developed eyes, Pecten have always been taken for study (except by WrLl and Srebold) and no mention of the anatomy of the eyes of other forms given, except that they were similar organs.

The following species of Pecten have been studied: $P$. jacobaeus, by Poli, Grube, Krohn, Hensen and Hrckson; $P$. opercularis by Grube and Hrckson; P. varius by Grube, and $P$. maximus by Duvernor, Keferstern and Hrckson. The species studied by Garner is not given, but is probably $P$. maximus. WILL and Siebold's species are not given.

As the anatomy and histology of this so-called eye are so well known, I will only give a brief account of it; and I may add the species $P$. hastatus and $P$. magellani to the number examined.

The eyeball is placed on a stalk or pedicle, which is covered by a pigmented layer of epitbelium, which extends into the eyeball as far as the edge of the so-called cornea; here the epithelial layer looses its pigment and becomes transparent and forms the anterior part of the ball; HeNser did not find this epithelial layer, but thought it might be present. From the observations of Hrckson and Sснмint and my own preparations I do not doubt the existence of it.

The cells of the pigmented epithelium have a strange form and are worthy to be taken up and considered in detail. They bear a close resemblance to the pigmented cells that I have described for Ostrea. Two thirds of their length is filled with pigment (fig. $15 a$ and $b$ ) and Hensen says that from some of his preparations he thouglit that they might possess cilia (fig. 15 b). He further adds that the cells give the impression of being organs for the perception of light. My preparations show similar cells, although no evidences of cilia are present. It may be that $I$ have not bandled the object with sufficient care.

The eye is made up of, anteriorly the cornea, consisting of the transparent epithelium resting on a hyaline membrane. which is a thin continuation of the connective tissues of the stalk. The lens which fills the space immediately behind the cornea is large and made up of nucleatcd cells. The lens is considered to be a spherical body by both Kroun and Keferstern, while Hrckson considers it elliptical. Hensen considers the cells making up the so-called lens to fill up the space between the retina and the anterior wall of the eye, making the shape of an irregular biconvex form. This latter statement $I$ am inclined to 
believe to be the correct one and I am inclined to consider that the definite deseribed shape is dne to contraction from the use of reagents; and then Hrckson says that when removed, in the fresh eondition, it is not elliptical as in hardened seetions, which he explains as being due to relaxation of its ligaments.

From the careful investigations of Hensen and preparations of my own I am led to believe that the lens fills up the whole space and is not the elliptical body figured and described by Hrckson.

Posterior to the lens is the retina, which extends across the middle of the eye, perpendicularly to the axis of the eye and stalk. It is separated from the posterior part of the eye by a thick layer of reddish pigment. According to Hicksos the retina is made up of five layers and to Hensen only of three. I do not consider it necessary to go into details concerning this part, as it differs somewhat in form in different species.

Posterior to the retina is the tapetum, which gives rise to the metallic lustre so striking in the living eye. Posterior to the tapetum and filling up the eavity between it and the posterior wall of the eyeball is a mass of red flnid pigment consisting of ma number of bright red granules«. A layer of eells according to Hensen forms the posterior part of the eye, the existence of which is denied by Hickson. I have preparations whieh demonstrate the existence of this layer and the distinct cells and nuelei beyond all shadow of donbt; in my ease however the cells are by no means as large nor as tall as those represented by HENSEN, and are not pigmented.

The nervous supply of this organ is ivery eomplieated; two nerve branches entering at two different points. The nerve eomes from the cireumpallial nerve, as do nerves passing to the tentacles between which the eye is situated. The branch which passes to the organ in question divides into two branehes, onc passing into the base of the ball called by Hickson the complementary nerve and the other he calls the retinal, which passes up and enters the side of the ball and is distributed to the anterior surface of the retina.

The question as to the function of this organ is one of considerable interest. HrCKson states that a few experiments have been made on this subjeet, concerning the visual power of this animal, and he says: "It is very doubtful whether they (the so-called eyes) are of much value to the animal in aroiding its enemies. The most reasonable theory of their funetion seems to be that when on the ebbing of the tide, a probability arises that they will be left high and dry on the shore, they ean appre- 
ciate the fact by the growing intensity of the light, and by that pecnliar flapping motion of the valves the Pectens are so remarkable for, move away into deeper water" ${ }^{1}$.

This theory may at once be set aside when we consider that the Pectens of the Mediterranean, where we have practically no tide at all, a state of affairs that has existed for an exceedingly long period of time, have as well developed eyes as those found on shores where tides do exist; and further it seems hardly probable that such a complicated organ would have developed to determine for the animal, whether it be out of water or not.

Now I am inclined to believe, as has been suggested by Hensen 2 , that the pigmented epithelial cells that cover this organ and the stalk on which it is situated, and the only place where we find a marked deposit of pigment, is the seat of vision for these animals and that the so-called eye may be an organ of some other sense, as suggested by SCHMmot ${ }^{3}$. If this sipposition be correct we should have the sense of vision of the same grade as that of other Lamellibranchs. If the organ in question is so highly developed, we must necessarily conclude that vision, if this be the sense, is also highly developed, which does not appear to be the case. And were this organ an eye of high grade its advantage to the animal conld not be very great, as the food and safety of the animal does not require such perfected vision. The pigmented cells (fig. 15) with the refractive ends, seem to answer the limited vision that they possess.

As regards the complicated organ known as the eye, I might suggest that, if this be an eye, it is one where we have no true pigmented layer in any direct relation to either the nerve or the retina. The mass of red pigment and the metallic-like tapetum would hardly answer the place of the black choroid coat so essential to the eye.

\section{Fam. Limidae.}

The species of Lima examined by GRUBE is not given neither does he consider the anatomy of the eye. He merely states that Pecten and Lima are the only Lamellibranchs that can see, and then considers only the anatomy of the eye of Pecten.

The tentacles fringing the border of Lima squamosa; the only

1 S. J. Hickson, The eyc of Pecten etc. 1850 . p. 454.

2 V. Hensen, Über das Auge ciniger Cephalopoden etc. 1565. p. 221.

3 E. O. Scmint, Handbuch der vergleich. Anatomic etc. 15\$2. p. 151. 
species that I have had opportunity to examine are comparatively very long, but have no pigment deposited in them whatever; neither conld I find any trace of pigment at the bases of the tentacles to sustain the fact that, according to GRUBE, Lima can see.

\section{Fam. Spondylidae.}

The investigator's who have mentioned that Spondylus possess eyes are Poli, Garner, WILL, and Hickson. The only one who entered upon the anatomy and histology was Hickson, who finds the form of the organ essentially the same as the so-called eye of Pecten. The species investigated by PoLI was Spondylus gaederopus, the other authors did not give the specific name.

Although it has not been mentioned whether the pigmented cells of the epidermis of the eye and stalk of Spondylus are capped with a refractive cuticula, I feel quite sure in stating that such exists, as the organs are so similar in every respect to those of Pecten. Hicrson did not observe them even in Pecten and consequently did not mention it, in the short account of Spondylus.

\section{Fam. Pinnidue.}

I am unable to find out the species investigated by WILL and SIEBOLD and further have not had the opportunity of examining any specimens. Vision is no doubt present as the observations of WILL and Siebold are smpported by Gegenbaur, but I am very doubtful, if any complicated organ is present.

\section{Fam. Aviculidae.}

I have had the opportunity of examining a species of Avicula from Panama (A. sterna?). As far as I know this genus has never been inrestigated as regards vision and so $I$ have no experimental proof of such. The whole edge of the mantle is well furnished with tentacles, at the bases of which are found well defined pigmented groores. On the cone-shaped tentacles abont half-way up was found a pigmented band, that extended around the cone and in breadth was about equal to half the height of the cone.

These conish tentacles were comparatively short and measured from about $1 \mathrm{~mm}$ to $2,5 \mathrm{~mm}$ in length. I conld find no trace of specialized eyes. I am inclined to believe that these pigmented grooves and bands answer the purpose of vision. The animal was not in a fit condition to settle the question by sections, and so I lave to conclude from 
the general resemblance to other forms where the point is settled beyond question of doubt.

\section{Fam. Mytilialce.}

Mytilus ectulis. I have unfortunately not had opportunity to observe whether this animal retracts the edge of the mantle when a shadow passes over it, but the character of the pigmented cells that line the edge of the mantle so agree with those forms that have vision, that I do not hesitate to say that vision exists, especially as this is one of those forms stated by WILL to possess highly complex eyes.

The mantle-cdge in this species is not fringed with tentacles, but is thrown into folds between which the pigmented cells are found. Into the most external fold as in Ostrea extends the cuticula, which here is much thicker than in Ostrea; at the base of this fold is attached a muscle, the retractor. The extensor muscle is also present, but is not so distinctly marked off into bundles as that described for Ostrea. The circumpallial nerve is situated a little distance from the base of the 2 . fold.

The epithelial covering may here also be divided into two categories. Those which form the nacre of the shell situated on the external face of the mantle and the more distinct columnar cells among which are found the pigmented ones, in relatively the same proportion as in Ostrea.

These pigmented cells are much longer than those of Ostrea being about four times as long but not much broader (comp. fig. 2 and 3$)^{1}$. They have a broad base which is directed outwards, then tapers to nearly a point where they rest on the tunica (fig. $3 t$ ). The pigment, which is of a dark brown color, occupies about one fifth to one sixth of the cell. The nuclei are large and distinct and are situated in the granular protoplasm of the cell near the pigment, that is, in the upper second fifth of the cell a little above where the commencement of the tapering begins.

We find in Mytilus as in Ostrea between the pigmented cells another set of cells, which have their broad ends resting on the tnnica (fig. $3 t$ ), while the narrow pointed end extcnds up between the large bases of the pigmented cells. Here also as in Ostrea I conld not satisfy myself, whether these pointed cnds were pigmented or not. This state of affairs seems only to exist when the seat of vision is on the mantle-

1 The figures $2,3,5,8,9$ and 16 are all drawn with a camera lucida of ZEISS with obj. Immersion No. 3 and ocular No. 3 , in order they would all be on the same scale to compare the sizes. 
edge, while no trace of this second set of cells is present in the forms with siphons.

These latter cells are filled with a granulated protoplasm, which seems to take less of the staining fluid than that of the pigmented cells, so that a contrast between these two sets of cells is formed. The nuclei are spherical and are placed in the broad ends of the cells, between the tapering ends of the pigmented cells.

Those pigmented cells, as well as the other cells that line the wall of the branchial chamber, I feel convinced are eiliated, and I am inelined to the same opinion as regards the eorresponding one in Ostrea, but I could not proove it entirely to my satisfaction, and consequently will not state that such is the case. Those cells situated in the folds then do not seem to have any trace of cilia.

Dreissensia polymorpha. Here also I am sorry to say that I have no experimental evidence of vision, but the anatomical structure agrees so exactly with other forms, on which I have experimented that I do not hesitate to say, that vision is present.

The mantle in this species is closed and with only a small byssal orifice; the siphon is only indieated by two specialized openings at the anterior part of the animal, in which considerable pigment is deposited.

When sections of these simple siphons are made, large and clearly defined cells are seen, which are somewhat smaller but much broader than those found on the mantle-edge of Mytitus. On those cells, in which pigment is found, a clear and refractive euticle is seen; this euticle is greatly developed and exceeds, in fact, that of any other Lamellibranch that $I$ have examined (fig. $16 \mathrm{c}$ ). The nuclei are long and large and the pigment is deposited between them and the cuticle (fig. 16).

These pigmented cells are deposited in a groove, which extends around the mouths of the siphons.

\section{Fam. Arcidcle.}

Arca incongrua was found to possess no trace of a deposit of pigment in the mantle. WILL, however, states that Arca has complicated eyes on the mantle, but I do not know what species he examined. In Arca americana there are erescent-shaped deposits of pigment at regular intervals a little above the mantle-edge on its cxterior surface, no other trace of visual organs are present.

Pectunculus sp. (?) The fact of this form possessing highly developed organs of sight, is known to me only through the works of WhLL, Siebold and GEGEnbaur; Siemoln stating that numerous brownish- 
red eyes were present in both Arca and Pectunculus. Gegexbaur also sustains the fact that the gencra possessed eyes.

\section{Fam. Cardiidae.}

I have had the opportunity of examining macroscopically the mantle-edge of Cardium muricatum, C. edule and C. magnum. WILL and SIEBOLD, both state that Cardium possesses eyes, the latter goes so far as to state, that the shining eyes are situated on the ends of contractile tentacles, which fringe the external openings of the two short mantle-tubes (siphon) and are extraordinarily numerous. I do not know the species examined by these anthors, but I can state as regards the speeies $C$. edule, $C$. muricatum and $C$. magnum, that not the slightest trace of any such organ was present, and further I could find no trace of a deposit of pigment. It is true, that the specimens that I examined, had been in alcohol for a long time and the deposit of pigment or small organs may have become destroyed.

\section{Fam. Veneridae.}

$V$ enus mercenaria. When the living siphon is extended, it projects but a few millimeters beyond the edge of the shell. When the siphon is cnt open, we find that the internal length is about $1,5 \mathrm{~cm}$. The external surface of the siphon is brownish and toward the orifices of the siphons it becomes peppered with black pigment being quite black at the very end. Internally the siphon presents a yellowish color also blackened toward the exterior opening.

If the mouths of the two apertures of the siphon be examined, they will be found to be fringed witl fine processes or tentaeles measuring about $1 \mathrm{~mm}$ in length. These tentacles are most numerous and best developed at the edge of the branchial siphon and very scarcc and small at the anal. A black line is seen to extend on the partition which divides the two siphons.

When sections are made of the end of the siphon, so that the wall is cut through parallel to its greatest length, we find on both sides of the scction, that is the external and interual surface of the siphon, a layer of well developed and distiuct columnar cells. This layer of epithelium is thrown into numerous folds as is seen in fig. 4. This layer of cells lies on the cutis, which is made up of comnective tissue and muscular fibcrs with distinct nuclei. In the middle of the wall of the siphon are seen numcrous parallel fibres, which, in conncetion with the retractor muscle, serve to withdraw the siphon. 
Among the columnar epithelial cells of the siphon are found pigmented ones scattered about in irregular groups, these are especially numerous near the external orifices of the siphon. The pigmented cells seem to be of the same size as those, which contain no pigment, and both are covered with a transparent covering, a cuticle.

The pigmented cells of Venus are by far the longest of any that I have examined (fig. 5). In shape they are similar to those of Mytilus, the cuticle however is much thicker in proportion. In Venus however we do not have any of the cells that lie between the tapering ends of the cells. A space is conscquently left here, which is due probably to the contraction of the protoplasm, the pigmented part of the cell being more dense, does not contract so much.

The nuclei of these cells are very long and narrow and more or less surrounded with the pigment (fig. 5).

Venus is another of the forms in which WILL found very complex organs of sight. I however have sought in vain for such organs; but I can assert that the animals perceive shadows, which pass over the extended ends of the siphons and they rapidly contract them.

Venus verrucosa is another species, that I have had opportunity to examine, and found the end of the siphon much pigmented and dark pigmented grooves at the bases of the tentacles.

In Tapes decussata well developed pigmented spots were found at the extremity of the siphons.

\section{Fam. Petricolidae.}

Petricola pholadiformis. Through the kindness of Mr. Fond, I have been able to examine several fresh specimens of this species. The siphons are large, and the branchial and anal siphons are not joined at the extremity. The ends of the siphons are morc or lcss pigmented at their external openings, these being more on the branchial than anal
siphon.

When sections are made the cells forming the pigmented spots are found to be essentially the same as the pigmented cclls already described. These cells differ, however, in the fact that the pigment is more or less collected at that part of the cell nearest the base, that is, where the cell is attached to the tumica. Hcre the pigment seems to be deposited around the nucleus learing the clear granulated protoplasm bctween the pigment and the transparcnt, homogencons cuticula. The pigmented epithelial cclls as a rule are placed at the base of slight folds, thus being more or less protected. 
In Saxidomus Nutallii (Conrad) the siphon is well developed and darkly pigmented at the extremity.

\section{Fam. Tellinidae.}

WILL states that Tellina is one of the forms, which have well developed eyes. I can safely say from the specimens, that I have examined of Tellina tenta, that I found not only no trace of eyes, but also no pigment deposit present.

\section{Fam. Mactridae.}

With Mactra solidissima I have had the opportunity to experiment and found the same sensitiveness to light and shadow that I have found in other species, with which I have experimented.

The siphon is well developed, not very long but quite robust. The external mouths of the siphon are densely fringed with tentacles from $1 \mathrm{~mm}$ to $2,5 \mathrm{~mm}$ in length, these tentacles are short and thick and really have more the appearance of cones than of tentacles.

When sections of this part are made and examined, we find no essential difference from those already described. The cells contain a brownish black pigment and are about the same length as those of Solen (fig. 9), the pigment being deposited next to the well marked and transparent cuticle. The pigmented cells here seem as in the preceding form to have a tendency to form into grooves or at the bases of the tentacles for protection, this being a step in advance of those forms, where the pigmented cells are simply scattered in the general epithelium.

In the other species that I have examined, Mactra ponderosa, the grooves were pale, but distinct at the base of the tentacles, and the siphon tolerably well developed.

\section{Fam. Myacidae.}

In Mya arenaria the siphon is from one to one and a half times the greater length of the shell; the whole is covered with a comparatively thick cuticnla, which is thrown into innumerable folds, when the siphon is contracted. This cuticula is a continuation of the cuticle, which covers the thick border of the mantle and the newly formed border of the shell. The cuticula is thinnest ncar the external end of the siphon.

The cnd of the siphon is quite black and pigment in spots occurs for quite a distance below the end. The mouths of the siphons are sur- 
rounded by tentacles, which are more distinct than in Venus mercenaria; there are three or four rows of tentacles the smallest outside and the largest inside, the onter ones measuring about $1 \mathrm{~mm}$ in length, while the inner are about twice as long $(2 \mathrm{~mm})$.

At the base of the inner and longer row of tentacles is seen an intensely black band, which passes around on the internal wall of the siphon, and is present in both the anal as well as the branchial siphon; at the basis of the other tentacles are seen little lines of black pigment.

When a longitudinal section of the wall of the siphon is made and somewhat magnified, we have a figure as is represented in fig. 6. At $a$ we have a section of the black band lying at the base of the internal row of tentacles; $c$ is one of the external tentacles showing a patch or groove of pigmented cells at each side of the base.

The substance of the siphon is seen made up of muscular fibers and connective tissue between the bundles of which are seen the lacunae (fig. 6 l).

When the patches of pigmented cells are more strongly magnified, we find that they are of greater length than the epithelial cells, which are not pigmented (fig. 7). We find that, as in the case of Mactra, the pigmented cells are concentrated into groups, where they are protected as at the base of the tentacles, or inside the siphon, but few are exposed at the external wall.

The cnticula which extends over the cells, is thickest on those cells, that are farthest from the edges of the groove or patch of cells (fig. 7), it gradually diminishes in thickness, so that none is present, where the unpigmented epithelium is reached. The pigment seems to be thickest, or most opaque, in the center of each cell, so as to give the cells the appearance of containing rods (fig. 7).

When the pigmented cells are examined with a high power, we find that they are essentially the same as thosc described for other species (fig. 8), save that the pigment instead of being dark brown is
jet black in color.

\section{Fam. Solenidae.}

Solen vagina. This is the form by which my attention was furst directed to investigate the visual organs of Lamellibranchiata, and with which I made the most extended and complete experiments, learing not the shadow of doubt, that visual power cxisted in these animals.

A preliminary account was published on November 6, 1583 ', ' B. Sharp, On Visual Organs in Solen. Proc. of Acad. of Nat. Sc. of Phila-
delphia. 1 583. p. 248 . 
giving the results of my observations on this genus. The siphon in this form is not long in proportion to the length of the animal, as we found it to be with Mya, but well developed. The mouths of the siphon are beset with short conical tentacles, which arc arranged in many rows. At the bases of the tentacles and well protected from injury are seen dark grooves, some of them being from 1 to $1,5 \mathrm{~mm}$ in length. These are very numerous and often as many as fifty or seventy five have becn counted in good sized individuals. WILL describes Solen as possessing eyes, unless he had reference to the pigmented grooves I could nowhere detect anything like an eye, especially one as complicated as he describes, although I have carefully examined the siphon both with a lens and by making long series of scctions of it.

These grooves are distinctly seen with the naked eye, and as these are the only places, where pigment is found, I think that we are safe in concluding that the seat of vision, which is undoubtedly present, is placed in these grooves.

When sections are made cutting the free end of the siphon vertically, we find that these grooves are composed of pigmented cells similar to those already described for other forms, and as a rule those cells situated at the base or bottom of the groovc are longer than those placed higher up. Occasionally when a collection of these cells line only one side of a groove as sometimes occurs, we find that those farthest from the edge are the longest as I have depicted in fig. 14.

When these pigmented cells are highly magnified (fig. 9), we find the nuclei almost if not absolutely spherical; the cells are typical cylindrical cells. The pigment is of a brown color and most dense at the free end of the cell and gradually diminishing as we approach the nucleus, the lower parts of the cells are filled with granular protoplasm. These cells do not seem to contract at the end in which the nuclei are placed as seems to be the case with similar cells of Venus (fig. 5) and Mya (fig. 8). Whether this is due to the fact, that Solen was more carefully prepared than the other two, or whether it is characteristic in $V$ enus and Mya I am not prepared to say.

No nerves could be detected in Solen nor in any other form that I have observed.

As regards Solen ensis I may say, that we have practically the same state of affairs. I could in no way detect any difference. I also had opportunity to experiment with this species and with just the same result as was obtained for Solen vagina; but as to Solen viridis, a small form, the siphons ended abruptly and there was no trace whaterer of 
tentaeles nor pigmented grooves. I do not know the habits of this form and never saw it alive, but from the form of the siphon and absenee of pigment I doubt if it has any power of vision.

Besides the pigmented cells were found other peculiar cells scattered here and there through the epidermis to which I will merely eall attention. These I have represented in fig. 10; they are clear cells situated between the eolimnar cells of the epidermis, the uuclei, situated near the tunica seem to be crescent-shape, this however may be due to the action of reagents - these cells are tolerably numerous and could be found in all the speeimens that I cut.

\section{Summary.}

In all the forms that I have examined, Spondylus and Pecten possibly exeepted, I find that the seat of vision rests in a number of pigmented epithelial cells, which have at the free end a fine homogeneous entiele, whieh is highly refractive. Although I could find no evidenee that nerves were distributed to these cells, it is reasonable to suppose that they are supplied with nerves as are the cells of the general epithelial surface. Now when we eompare these cells with those found in the eyes of Patella, situated at the base of the tentaeles, we find here a similar state of affairs. As is shown by Fraisse 1, the eye of Patella is a simple invagination of the epidermis, forming a sae whieh is open exteriorly, and allows free aceess to the surrounding medium, water. FraIsse could find no evidenee of nerves being distributed to this organ. The pigmented cells whieh lined this invagination were supplied with nerves that were distributed to the general epithelium as was the ease with the Lamellibranchiata, that I examined. The pigmented eells, which make up the eye of Patella (fig. 12), have essentially the same form as those found in the Lamellibranchiata. Now in the Lamellibranchiata we have eren a simpler form of visual organ, than that of Patella, for in Patella we have the organs speeialized in number, two, and situation - in the base of the tentacles at the anterior or oral end of the beast. In the Asiphonata the rision is very generalized - patehes of pigmented eells seattered at large at that portion of the animal most exposed to light and danger. A somewhat higher grade is seen in the Siphonata, where the pigment is more localized in the lower

1 P. FraissE, Über Molluskenaugen etc. 1981. 
forms, while much more so in Solen, Mactra etc. where the pigmented cells are in grooves at the base of the tentacles and protected by them.

Now the simplest form of organ capable of vision must have pigment to absorb the light and a refractory body, as is exemplified in the lowest known form of visual organ, the eye spot of Euglena viridis, a flagellate infusorian; here only a part of a cell acts as an organ of vision.

In Ostrea the conditions necessary for sight are present, a number of cells that contain piginent and have as their external surface a highly refractive body, the transparent cuticle, and that vision is present is proven by experiment ${ }^{1}$; further the fact that these cells are placed only where they could be of use to the animal. Morphologically eyes should be at the oral extremity of the animal, where we do find them in the larvae of some of the Lamellibranchiata ${ }^{2}$; but the organs of vision found in the adult are only physiologically eyes - adaptive or cenogenetic organs.

They are generalized and scattered more or less on the whole mantle, but principally at the posterior end, this we find to be more or less the case in all the Asiphonata. When a higher stage is reached, and a siphon begins as in Dreissensia polymorpha, we have the cells concentrated on that part of the mantle (siphon), which extends farthest from the shell. In Dreissensia and Venus where, when the animal is disturbed it retracts the siphon wholly within the shell, we have the pigment cells in spots on the surface of the siphon without any particular protection. In Mya, however, where the siphon can hardly be retracted within the shell, we have the pigment cells protected by being placed in grooves at the base of the tentacles, where in the rapid withdrawal of the siplion through the sand, in which the animal lives no injury to the delicate organs takes place.

A step higher we have the state of affairs in Solen and Mactra, when the pigmented grooves are only at the bases of the tentacles, and the grooves more or lcss specialized in number and complexity. A more highly developed or specialized type is Patella, where the grooves are specialized to a splierical pit, but still open and bathed with the surrounding medium.

These are probably the stcps taken in the pliylogenetic derelopment of the eyc, first gencral, then specialized to that part of the

1 J. A. Ryder, Primary Visual Organs etc. 1583.

2 C. Geginbaur, Elem. of Comp. Anat. ete. $187 \S$. $\$ 272$. p. 353. 
animal where it be of most use, and in the majority of cases this would be at the oral end of the animal; but in the Lamellibranchiata, where we have probably a degenerate group and the head atrophied or absent and not exposed to the light, the morphological eyes have become lost and other adaptive organs developed, where they would be of the greatest service.

We have therefore in the Lamellibranchiata, the obliteration through disuse of true and perhaps once tolerably well developed eyes and the formation of adaptive visual organs either in an early stage of derelopment or they have reached a state sufficiently bigh for the uses
of the animal.

In a higher form even than Patella we have an interesting advance as shown by Fraisse in Haliotis. Here we have a lens present, but the eye still open anteriorly; the pigmented cells, however, which form the ball of the eye have no trace whaterer of the refractive cuticle (fig. 13) seen in Patella and the Lamellibranchiata, the want being supplied by a distinct lens. Nerves also are so differentiated as to be
seen in this form.

I may add here that I saw no such appearance in the Lamellibranchiata, when I made transverse sections of the whole cell as made an error in stating, that the clear protoplasm extended to the surface as he represents. I had found that the cells of the Lamellibranchiata also were clear of pigment in the center, but by studying very thin sections and also oblique ones, I came to the conclusion, that this only existed at the lower part of the cell, when the pigment became deposited on the sides of the cells, at the ends, however, the whole was filled with pigment.

End of March 1884. 


\section{Explanation of Plate 26.}

Figures 2, 3, 5, 8, 9, 16 are all drawn to the same scale to give their relative sizes. Figures 11, 12, 13 are copied from FrAISSE and figure 15 enlarged twice from a figure by Hensen. The colored figures stained in borax carmine.

Fig. 1. Radial section (perpendicular to mantle-edge) of the edge of the mantle of Ostrea virginica: $a$ external, $b$ middle, and $c$ internal fold of mantle's edge; b.e. epithelium of the external wall of the branchial chamber; B.S. Branchial side of the mantle; b.s. blood spaces in the mantle; cu. cuticle of the shell; $d$ a branch of the retractor muscle $\left\langle r . m_{0}\right\rangle ; e . m$. extensor muscle; P.N. transverse section of the circumpallial nerve; s.e. epithelium, which lies next to the shell.

Fig. 2. Five pigmented retina cells from thc edge of the mantle of Ostrea virginica (for letters see text p. 453).

Fig. 3. Five similar cells from Mytilus edulis (for letters see text p. 460).

Fig. 4. Part of section of siphon of Venus mercenaria, showing the pigmented epithelinm.

Fig. 5. Five pigmented retina cells from the siphon of Venus mercenaria (letters as in fig. 2).

Fig. 6. Longitudinal section of the external end of the siphon of Mfya arenaria: $a$ internal band of pigmented cells; $b$ space between external and internal row of tentacles.

Fig. 7. Magnified view of base of tentacle marked $c$ fig. 6 .

Fig. 8. Four pigmented retina cells from the siphon of Mya arenaria (letters as in fig. 2).

Fig. 9. Three similar cells from Solen vagina (letters as in fig. 2).

Fig. 10. Epithelium from siphon of Solen ensis (for explanation see text p. 467).

Fig. 11. Transverse section of retina cells of Patella coerulca. The pigment collected on the walls of the cells (copied from FrAISSE, Taf. XXVI fig. 11).

Fig. 12. Three retina cells from the eje of Patella coerulea (copied from FraIsse, Taf. XXVI fig. 12).

Fig. 13. Six retina cells from the eye of Haliotis tubcrculata (copied from Fraisse, Taf. XXVI fig. 13).

Fig. 14. A group of retina cells of Solen vagina.

Fig. 15. Pigmented cells from epithelium of the eye of Pccten (copied [enlarged] from Hensen, Taf. XXI fig. $98 f$ and $f^{\prime}$ ).

Fig. 16. Four retina cells from the siphon of Dreissensia polymorpha (letters as in fig. $2 \%$. 


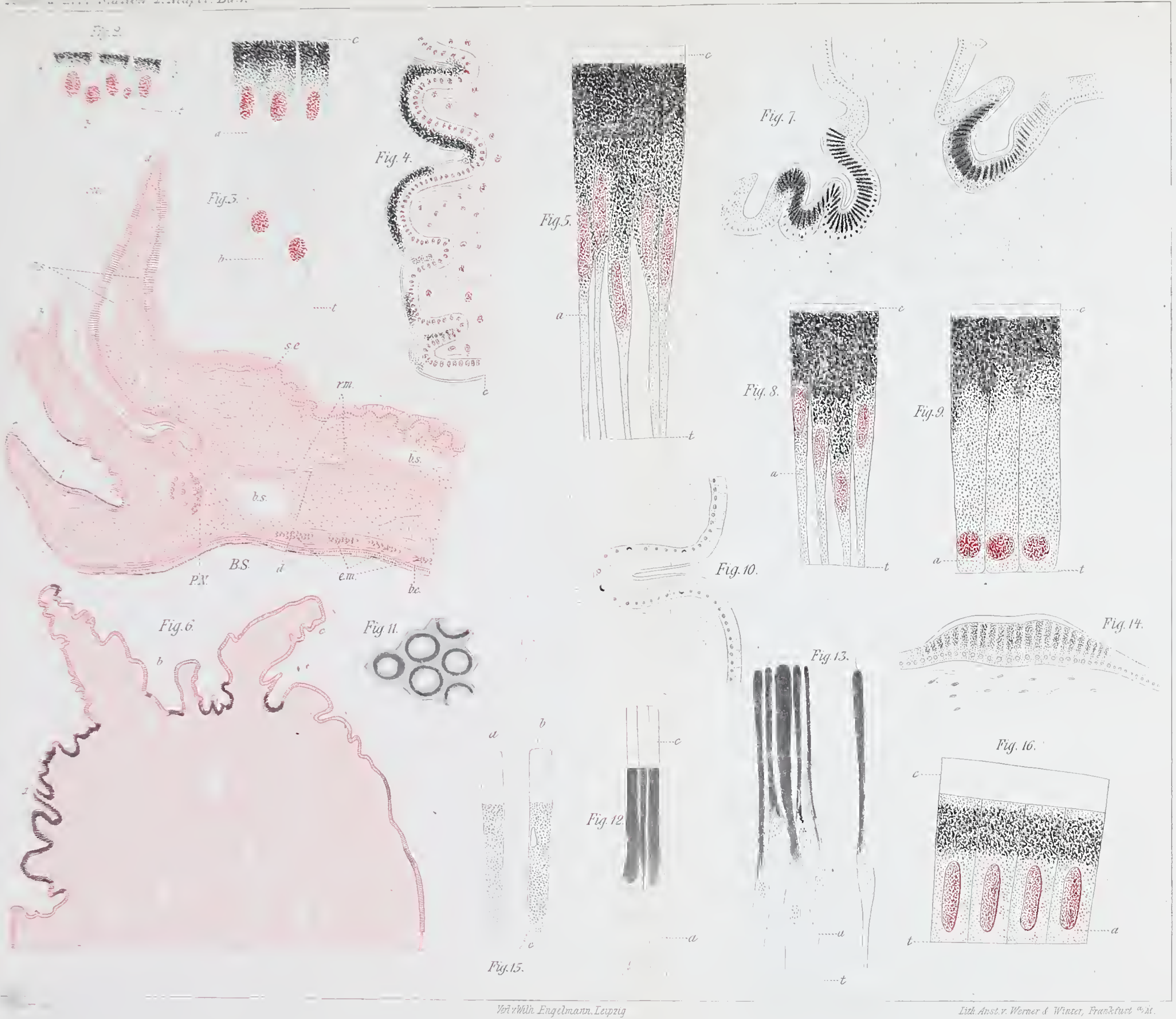





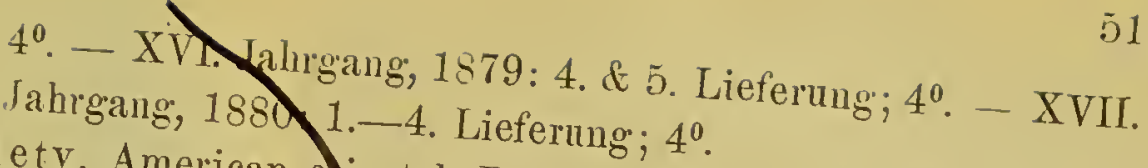

Society, American dental: Proceedings at New Haven, October $26^{\text {th }}, 1881$; 8 a

Vere in für Naturkunde zut vickau: Jahresbericht, 1879. Zwickan, $1880 ; 8^{\circ}$

- entomologischer, in Stocholm: Entomologisk Tidskrift Band I. Häft 1. Stockholm $880 ; 8^{\circ}$

Wiener Medizinische Wochensch HXXII. Jahrgang, Nr. 1

\& 2. Wien, 1882; $4^{0}$. 
